Anna Przelaskowska, Jolanta Klaja

Instytut Nafty i Gazu - Państwowy Instytut Badawczy

Piotr Kulinowski

Uniwersytet Pedagogiczny, Instytut Techniki

Adam Gaweł

AGH Akademia Górniczo-Hutnicza im. St. Staszica, Wydział Geologii, Geofizyki i Ochrony Środowiska

\title{
Zastosowanie metod analizy termicznej w badaniach skał silikoklastycznych o zróżnicowanym zaileniu
}

\begin{abstract}
W pracy przedstawiono możliwość zastosowania metod analizy termicznej w charakterystyce skał silikoklastycznych o zróżnicowanym zaileniu. Badania wykonano dla dwóch grup próbek: słabo zdiagenezowanych skał mioceńskich i fliszowych oraz mocno przeobrażonych mułowców dolnopaleozoicznych. Dla wszystkich próbek przeprowadzono pomiary symultanicznej analizy termicznej STA, sprzężone ze spektrometrią masową QMS. Analiza wykonanych badań pozwoliła na określenie zakresów temperatur i ubytków masy charakterystycznych dla takich procesów jak: dehydratacja i dehydroksylacja minerałów ilastych, spalanie substancji organicznej i rozkład węglanów.
\end{abstract}

Słowa kluczowe: analiza termiczna, kwadrupolowy spektrometr masowy, minerały ilaste.

\section{Thermal analysis of siliciclastic rocks of different clay content}

The possibility of applying thermal methods to the characterization of siliciclastic rocks of different clay content was studied in the presented work. Two series of samples were investigated: highly diagenetic lower Paleozoic mudstones and less altered Miocene and Flysch rocks. Simultaneous thermal analysis STA coupled with mass spectrometry QMS was conducted for all samples. The reaction temperatures and mass changes of such processes as: dehydration and dehydroxylation of clay minerals, thermooxidative decomposition of organic substance and carbonates were determined.

Key words: thermal analysis, quadrupole mass spectrometer, clay minerals.

\section{Wstęp}

Charakterystyka własności zbiornikowych skał wymaga określenia takich parametrów jak: porowatość całkowita, porowatość efektywna, przepuszczalność, rozkład nasyceń przestrzeni porowej płynami złożowymi. W związku $\mathrm{z}$ tym, że w ostatnich latach zainteresowanie firm poszukiwawczych skupiało się na badaniach skał zbiorników niekonwencjonalnych, wiele metod badawczych rozwinęło się lub zostało zaadaptowanych do badań skał mikroporowych. Jedną z takich metod jest analiza termiczna.

Metody analizy termicznej wykorzystywane są do badania przemian fazowych i reakcji chemicznych zachodzących $w$ trakcie ogrzewania analizowanych substancji.
W badaniach minerałów i skał metody te stosowane są od lat 60. ubiegłego wieku. W Polsce prekursorem pomiarów termicznych był profesor Leszek Stoch, który zastosował je w badaniach surowców mineralnych, a w szczególności minerałów ilastych [9]. Rozwój metod termicznych w badaniach skał umożliwił powstanie przeglądowych opracowań zawierających szerokie spektrum termogramów minerałów skałotwórczych wraz z analizą [2]. Prace takie są niezwykle pomocne w interpretacji wyników pomiarów wykonanych badań. Analiza termiczna skał znalazła również zastosowanie w szacowaniu wody związanej z iłami w łupkach gazonośnych [3, 7]. 
Problemy ze zdefiniowaniem porowatości całkowitej i efektywnej, rozróżnieniem pomiędzy wodą ,wolną" a „Związaną” w skałach mikroporowych wiążą się, między innymi, z wysoką zawartością iłów oraz w efekcie tego - dużymi ilościami wody „nieruchomej” związanej w różny sposób z minerałami ilastymi (woda zaadsorbowana, związana z warstwą podwójną, woda kapilarna, woda międzypakietowa). Celem pracy było zbadanie możliwości zastosowania metod analizy termicznej w charakterystyce skał mikroporowych o zróżnicowanym zaileniu. Badania wykonano dla dwóch grup próbek: słabo zdiagenezowanych skał mioceńskich i fliszowych oraz mocno przeobrażonych mułowców dolnopaleozoicznych.

\section{Materiały i metody}

Przebadano 14 próbek skał o różnym stopniu zailenia. Skały te reprezentowane są przez piaskowce, mułowce i iłowce miocenu zapadliska przedkarpackiego zawierające słabo zdiagenezowane iły o dużych zdolnościach do pęcznienia, piaskowce fliszowe oraz mułowce i iłowce dolnopaleozoiczne mające w swoim składzie mocno zdiagenezowany materiał ilasty o charakterze illitowym. W celu przeprowadzenia analizy porównawczej wyników uzyskanych metodą analizy termicznej z innymi parametrami charakteryzującymi materiał skalny wykonano badania składu mineralnego, pojemności wymiany kationowej CEC oraz zawartości substancji organicznej TOC. Skład mineralny skał określono na podstawie ilościowej analizy rentgenowskiej [6]. Pomiary pojemności wymiany kationowej przeprowadzono spektrofotometryczną metodą heksaaminy kobaltowej [8]. Badania zawartości substancji organicznej wykonano metodą pirolizy Rock Eval w Zakładzie Geologii i Geochemii INiG - PIB. Skład mineralny badanych skał jest bardzo zróżnicowany, zawierają od 30 do $60 \%$ kwarcu i skaleni, od 28 do $65 \%$ minerałów ilastych, zmienne ilości węglanów i siarczków żelaza (rysunek 1). Wartości pojemności wymiany kationowej charakteryzują się dużą zmiennością: od 1,68 mval/100 g dla piaskowca fliszowego o niskim zaileniu do $20,9 \mathrm{mval} / 100 \mathrm{~g}$ dla iłowca mioceńskiego. Zaobserwowane zróżnicowanie wartości CEC związane jest zarówno z ilością iłów, jak i z ich rodzajem. Najwyższymi wartościami CEC (powyżej 15 mval/100 g) charakteryzują się iłowce i mułowce mioceńskie. Próbki dolnopaleozoiczne wykazują znacznie niższe wartości CEC (średnio około 5 mval/100 g). Badane skały charakteryzują się dużym zróżnicowaniem całkowitej zawartości węgla organicznego TOC: od $0,12 \%$ dla piaskowca fliszowego do $5,35 \%$ dla mułowca dolnopaleozoicznego.

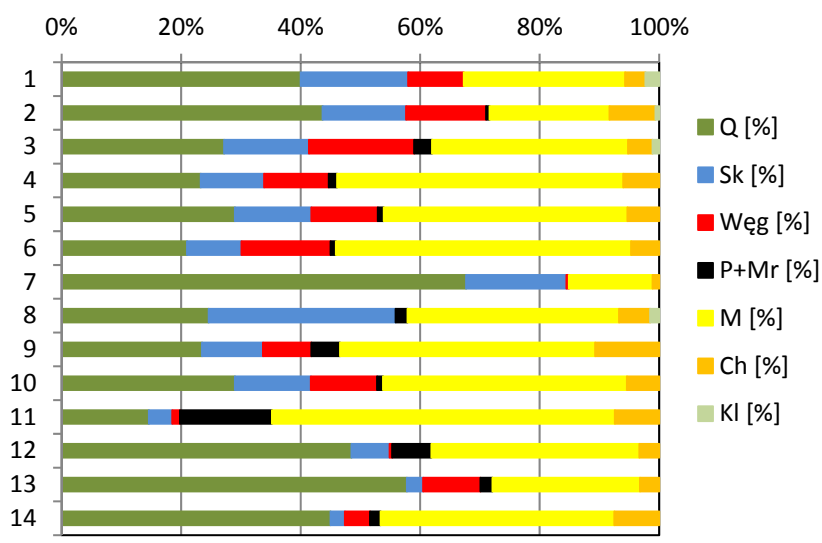

Rys. 1. Skład mineralny badanych skał. Objaśnienia: $\mathrm{Q}$ - kwarc, Sk - skalenie, Węg - węglany, $\mathrm{P}+\mathrm{Mr}$ - piryt i markasyt, $\mathrm{M}$ - miki i minerały grupy illitu, $\mathrm{Ch}$ - chloryt, $\mathrm{Kl}$ - kaolinit

\section{Metodyka analizy termicznej}

Metody analizy termicznej wykorzystywane są do badania przemian fazowych i reakcji chemicznych zachodzących w trakcie ogrzewania badanych substancji. Symultaniczna analiza termiczna STA polega na rejestracji zmiany masy badanej substancji TG, jej temperatury $T$ oraz różnicy temperatur próbki badanej i referencyjnej (DTA - termiczna analiza różnicowa) w funkcji czasu, podczas ogrzewania ze stałym w czasie przyrostem temperatury. Zwykle system pomiarowy pozwala na zapis danych w funkcji temperatury. Wykreślane są: krzywa termograwimetryczna TG, pierwsza pochodna TG względem temperatury DTG oraz krzywa DTA pozwalająca na uzyskanie informacji o rodzaju przemian (przemiany egzotermiczne, endotermiczne) zachodzących w próbce.
Interpretacja wyników badań termoanalitycznych nie nastręcza z reguły trudności w przypadku badania pojedynczych faz. Zazwyczaj jednak mamy do czynienia z układami wieloskładnikowymi, gdzie temperaturowe zakresy poszczególnych etapów badanych procesów nakładają się na siebie, co utrudnia interpretację wyników. Dlatego też wskazane jest połączenie analizy termicznej z innymi metodami umożliwiającymi analizę wydzielonych podczas reakcji gazów. Wykorzystuje się tutaj metodę spektrometrii masowej, w której badany gaz jest jonizowany, po czym następuje separacja zjonizowanych atomów/cząsteczek ze względu na stosunek wartości masy do ładunku. W wyniku pomiaru uzyskiwane są wartości prądów jonowych odpowiadające poszczególnym stosunkom m/z, czyli tzw. widma masowe. 
Dla wszystkich próbek przeprowadzono pomiary symultanicznej analizy termicznej STA. Wykonano je na aparacie STA 449F3A firmy NETZSCH w laboratorium Wydziału Geologii, Geofizyki i Ochrony Środowiska AGH. Próbki mierzono w zakresie temperatur od $30^{\circ} \mathrm{C}$ do $1000^{\circ} \mathrm{C}$, z krokiem $10^{\circ} \mathrm{C}$ na minutę, w atmosferze sztucznego powietrza. Przyjęto naważkę około $50 \mathrm{mg}$ (50,07 do 50,55 mg) próbki rozdrobnionej do wielkości ziarna $<0,1 \mathrm{~mm}$. Zastosowanie kwadrupolowego spektrometru masowego (QMS) sprzężonego $\mathrm{z}$ analizatorem termicznym umożliwiło przeprowadzenie analizy gazów uwalnianych w trakcie pomiaru. Analizę gazów wykonano pod kątem zawartości $\mathrm{CO}_{2} \mathrm{i} \mathrm{H}_{2} \mathrm{O}$, co okazało się niezmiernie przydatne dla interpretacji poszczególnych efektów widocznych na krzywych termicznych.

\section{Wyniki}

Uzyskane wyniki pozwoliły na określenie ubytków masy związanych z takimi procesami zachodzącymi w próbce pod wpływem temperatury jak: dehydratacja i dehydroksylacja minerałów ilastych, spalanie substancji organicznej i rozkład węglanów.

Na rysunkach 2 i 3 przedstawiono zestawienia krzywych TG-DTG-DTA-QMS dla wybranych próbek: krzywa termograwimetryczna TG (zielona linia), zróżniczkowana krzywa

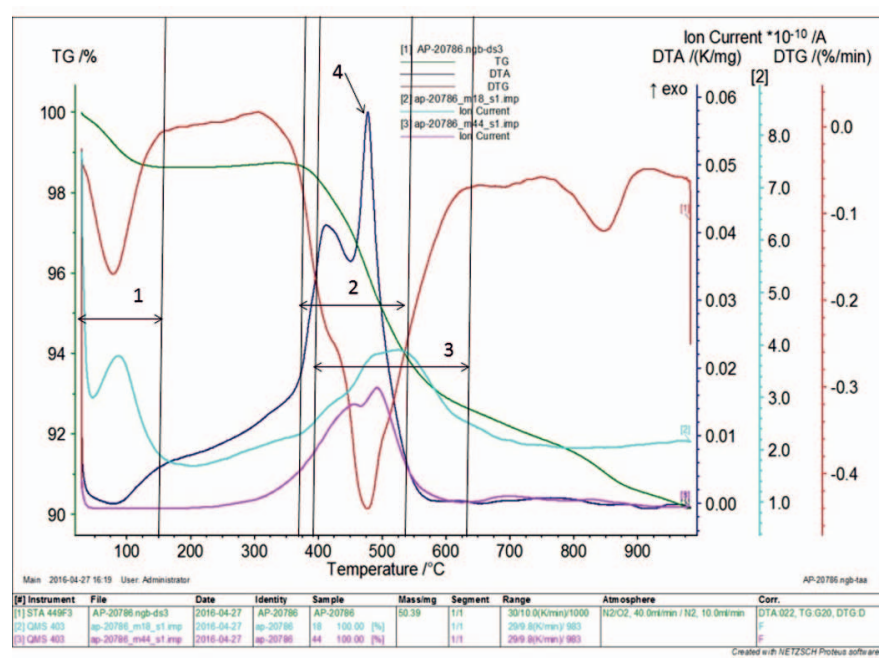

Rys. 2. Wynik analizy termicznej (TG-DTG-DTA-QMS) iłowca mioceńskiego zawierającego 53,9\% iłów i 0,91\% TOC (próbka 4)

Objaśnienia: 1) $40^{\circ} \mathrm{C}$ do $160^{\circ} \mathrm{C}$ - dehydratacja iłów, ubytkowi masy towarzyszy wyraźna reakcja endotermiczna oraz refleks na widmie masowym $\mathrm{H}_{2} \mathrm{O}$; 2) $300^{\circ} \mathrm{C}$ do $480^{\circ} \mathrm{C}$ - rozkład substancji organicznej, ubytek masy połączony z pikami egzotermicznymi oraz refleksem na widmie masowym wody $\left(300^{\circ} \mathrm{C}\right)$ i refleksami na widmie masowym $\mathrm{CO}_{2}$; 3) $450^{\circ} \mathrm{C}$ do $620^{\circ} \mathrm{C}$ - dehydroksylacja iłów, ubytkowi masy towarzyszy reakcja endotermiczna oraz refleks na widmie masowym $\mathrm{H}_{2} \mathrm{O}$; 4) $675^{\circ} \mathrm{C}$ do $770^{\circ} \mathrm{C}$ - rozkład węglanów, ubytkowi masy towarzyszy bardzo wyraźny efekt endotermiczny oraz duży refleks na widmie masowym $\mathrm{CO}_{2}$; 5) $895^{\circ} \mathrm{C}$ - rekrystalizacja chlorytu (prawdopodobnie), efekt egzotermiczny bez ubytku masy termograwimetryczna DTG (czerwona linia), krzywa różnicowa DTA (ciemnoniebieska linia) oraz widma masowe charakterystyczne dla wody (stosunek masy do ładunku $\mathrm{m} / \mathrm{z}=18$, jasnoniebieska linia) i dwutlenku węgla (stosunek masy do ładunku $\mathrm{m} / \mathrm{z}=44$, różowa linia). $\mathrm{W}$ tablicy 1 przedstawiono wyniki interpretacji pomiarów termicznych - zakresy temperatur i ubytki masy charakteryzujące poszczególne procesy zachodzące w próbce.

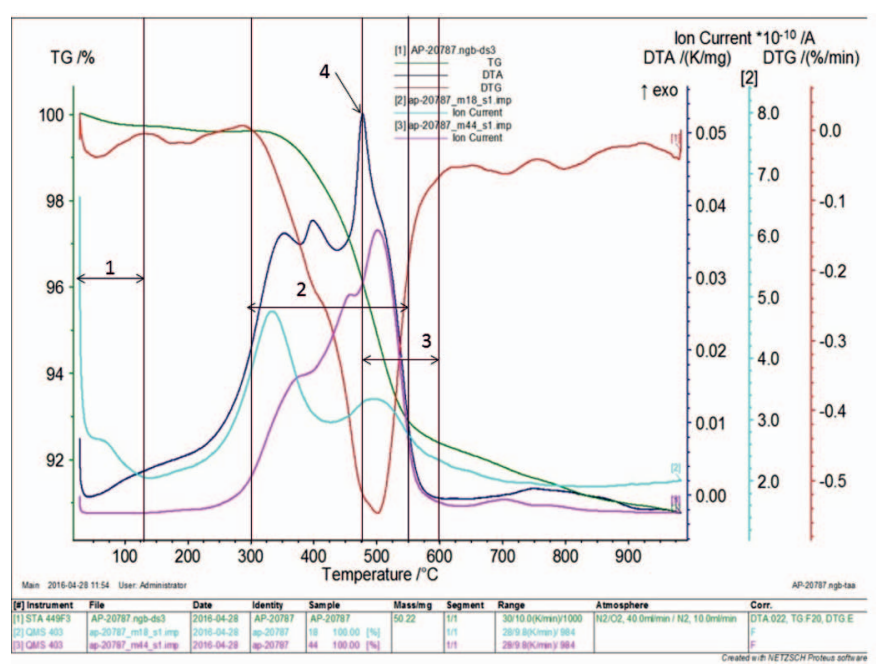

Rys. 3. Wynik analizy termicznej (TG-DTG-DTA-QMS) mułowca dolnopaleozoicznego zawierającego 38,1\% iłów i 5,35\% TOC (próbka 12)

Objaśnienia: 1) $40^{\circ} \mathrm{C}$ do $130^{\circ} \mathrm{C}$ - dehydratacja iłów, nieznaczny ubytek masy $\mathrm{z}$ towarzyszącym mu refleksem na widmie masowym $\mathrm{H}_{2} \mathrm{O}$; 2) $300^{\circ} \mathrm{C}$ do $550^{\circ} \mathrm{C}$ - rozkład substancji organicznej, ubytek masy połączony z wyraźnymi efektami egzotermicznymi oraz refleksem na widmie masowym wody $\left(300^{\circ} \mathrm{C}\right)$ i refleksami na widmie masowym $\mathrm{CO}_{2}$; 3) $480^{\circ} \mathrm{C}$ do $600^{\circ} \mathrm{C}$ - dehydroksylacja iłów, ubytkowi masy towarzyszy reakcja endotermiczna oraz refleks na widmie masowym $\mathrm{H}_{2} \mathrm{O}$; 4) $475^{\circ} \mathrm{C}$ - utlenianie pirytu, ubytkowi masy towarzyszy efekt egzotermiczny

\section{Ubytek masy związany z iłami}

\section{Woda zaadsorbowana}

W zakresie niskotemperaturowym (temperatury poniżej $150^{\circ} \mathrm{C}$ ) uwalniana jest woda wolna, związana siłami kapilar- nymi oraz woda zaadsorbowana na powierzchniach i w przestrzeniach międzypakietowych iłów [2, 3, 4]. Proces uwalniania wody międzypakietowej ze smektytów i iłów mie- 


\begin{tabular}{|c|c|c|c|c|c|c|c|c|c|c|c|c|c|c|c|c|c|c|}
\hline & $\Xi$ & 0 & 0 & 0 & & & & & & & & & 2 & 2 & & & \multirow{2}{*}{\multicolumn{2}{|c|}{ 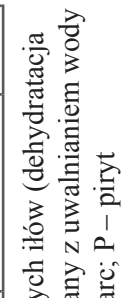 }} \\
\hline \multicolumn{2}{|c|}{ 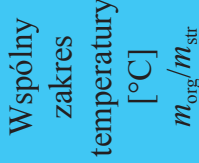 } & 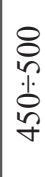 & $\stackrel{\infty}{\infty}$ & 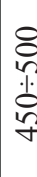 & $\begin{array}{l}8 \\
a \\
y \\
y \\
y \\
y\end{array}$ & , & 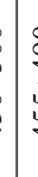 & & 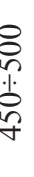 & $\begin{array}{l}n \\
\text { है } \\
\text { के }\end{array}$ & 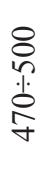 & 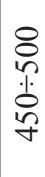 & $\mid \begin{array}{l}n \\
\hat{n} \\
\hat{2} \\
2 \\
\tilde{n}\end{array}$ & 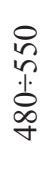 & & $£$ & & \\
\hline \multirow{3}{*}{ 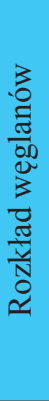 } & $\sum b^{\circ}$ & $\begin{array}{l}\infty \\
m \\
m\end{array}$ & gุ & f? & 7 & a & 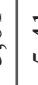 & & $\frac{\infty}{0}$ & & $\begin{array}{l}\stackrel{2}{\circ} \\
\text { ले }\end{array}$ & $\begin{array}{l}\stackrel{2}{f} \\
\stackrel{7}{*}\end{array}$ & & & $\forall$ & s & & \\
\hline & 垱导 & $\dddot{n}$ & 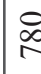 & $\frac{1}{n}$ & $\frac{1}{7}$ & 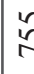 & 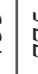 & & & & 옴 & in & & & $\Re$ & 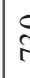 & & \\
\hline & 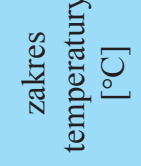 & \begin{tabular}{l}
2 \\
\multirow{1}{*}{} \\
$\stackrel{1}{0}$ \\
$\infty$ \\
0
\end{tabular} & $\begin{array}{l}\curvearrowright \\
\stackrel{2}{p} \\
\stackrel{1}{2}\end{array}$ & $\begin{array}{l}8 \\
\vdots \\
1 \\
1 \\
\alpha \\
\alpha\end{array}$ & 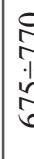 & 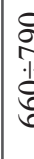 & i & & 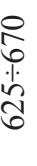 & &  & 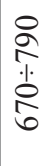 & & & $\begin{array}{l}\text { 2 } \\
\text { 览 }\end{array}$ & & & \\
\hline \multicolumn{2}{|r|}{$\equiv 0^{\circ}$} & $\begin{array}{l}\infty \\
\text { n } \\
\text { n. }\end{array}$ & & ले & 5 & తి & & & in & $\hat{i}$ & $\overrightarrow{\text { ñ }}$ & $\begin{array}{l}n \\
\text { nn }\end{array}$ & $\begin{array}{l}\overrightarrow{0} \\
\therefore \\
\therefore\end{array}$ & $\begin{array}{c}\infty_{0} \\
\dot{m}^{2}\end{array}$ & $\stackrel{5}{\sim}$ & 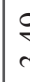 & & \\
\hline \multirow[t]{2}{*}{ 范 } & $\approx e^{\circ}$ & it & ก. & r & 2 & 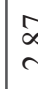 & & & $\begin{array}{l}\hat{n} \\
\hat{0}\end{array}$ & $\approx$ & $\stackrel{\text { in }}{i}$ & $\bar{m}$ & $\begin{array}{l}\infty \\
\infty \\
i\end{array}$ & $\underset{\sim}{\sigma}$ & s & a & & \\
\hline & 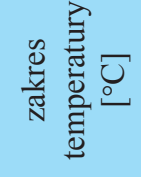 & 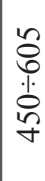 & है & 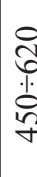 & $\mid \begin{array}{l}0 \\
0 \\
0 \\
1 \\
15 \\
y\end{array}$ & 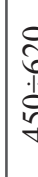 & & & 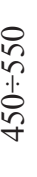 & $\begin{array}{l}8 \\
0 \\
1 \\
8 \\
0\end{array}$ & $\begin{array}{l}\text { त̂ } \\
\text { 光 } \\
\text { \& }\end{array}$ & 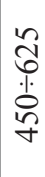 & $\begin{array}{l}0 \\
0 \\
0 \\
1 \\
0 \\
0 \\
\text { r }\end{array}$ & $\begin{array}{l}n \\
0 \\
0 \\
1 \\
\infty \\
\infty\end{array}$ & 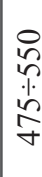 & & & \\
\hline \multirow{3}{*}{ 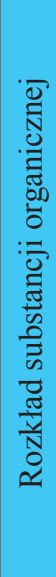 } & $\approx 0^{\circ}$ & $\stackrel{\infty}{\infty}$ & 8 & 尹 & ? & ఠ & & & $\frac{N}{0}$ & बे & $\stackrel{0}{\infty}$ & $\frac{\infty}{0}$ & $\begin{array}{l}\mathcal{I} \\
\stackrel{\sim}{*}\end{array}$ & $\frac{0}{6}$ & $\frac{\sigma}{\sigma}$ & 5 & & \\
\hline & + & & & $\stackrel{2}{4}$ & 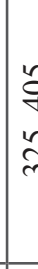 & 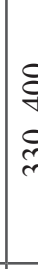 & & & & & $\stackrel{n}{\infty}$ & & & 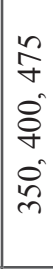 & $\begin{array}{l}n \\
\infty \\
+ \\
n \\
o \\
+ \\
n \\
n\end{array}$ & (5) & & \\
\hline & 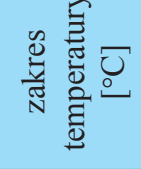 & $\begin{array}{l}8 \\
0 \\
1 \\
0 \\
0 \\
0\end{array}$ & $\underset{d}{\infty}$ & 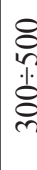 & 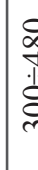 & 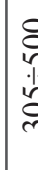 & & & 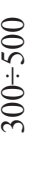 & 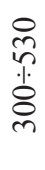 & 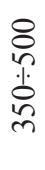 &  & $\mid \begin{array}{l}n \\
\hat{n} \\
\hat{2} \\
0 \\
m\end{array}$ & 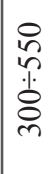 & $\begin{array}{l}0 \\
\hat{n} \\
\stackrel{2}{8} \\
0\end{array}$ & $\delta$ & & \\
\hline \multirow{3}{*}{ 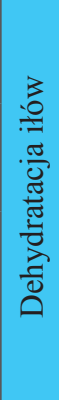 } & $\stackrel{\frac{n}{5}}{\Xi}$ & $\frac{t}{0}$ & & $\alpha$ & 气̄ & 5 & & & 1 & $\stackrel{8}{-}$ & $\stackrel{\infty}{+\infty}$ & ơ & $\vec{\sim}$ & ñ & 1 & g & & \\
\hline & 曾可 & 8 & & ఠ & 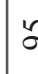 & $y$ & & & & & ๙ & $\approx$ & & & & & & \\
\hline & 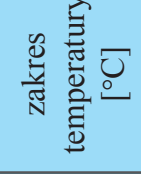 & 导 & 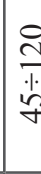 & $\frac{n}{\frac{1}{1}}$ & v & s & & & | & $\stackrel{\text { I }}{-}$ &  & $\frac{\text { P }}{\stackrel{p}{r}}$ & $\mid \begin{array}{l}n \\
n \\
\frac{n}{q} \\
q\end{array}$ & $\frac{a}{2}$ & & & & \\
\hline \multirow{2}{*}{\multicolumn{2}{|c|}{ 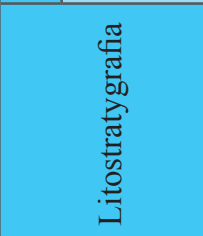 }} & $\stackrel{1}{a}$ & I & 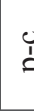 & $\therefore$ & 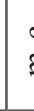 & & $\underline{L}$ & 1 & $i$ & $\dot{\Xi}$ & $\stackrel{i}{i}$ & $\frac{0}{1}$ & i & 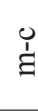 & 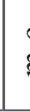 & & \\
\hline & & \multicolumn{6}{|c|}{ иәэо!ш } & & & & \multicolumn{6}{|c|}{ 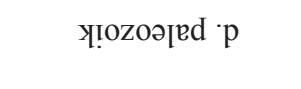 } & & \\
\hline & 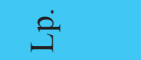 & - & & 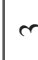 &  & & & & r & $\infty$ & $a$ & 으 & $=$ & $\simeq$ & $n$ & 7 & & \\
\hline
\end{tabular}

szanopakietowych obserwowany jest także w temperaturach nieco wyższych - do około $200^{\circ} \mathrm{C}$ [2]. W większości badanych próbek ubytek masy zauważono w zakresie temperatur od $40^{\circ} \mathrm{C}$ do $150^{\circ} \mathrm{C}$. Efektowi temu odpowiada pik endotermiczny na krzywej DTA oraz refleks na widmie masowym wody (QMS). W skałach o niskim zaileniu nie stwierdzono ubytku masy (próbki 7, 13) lub jest on bardzo nieznaczny (próbka 2), co świadczy o tym, że na krzywych DTA nie obserwujemy efektów związanych z uwalnianiem wody wolnej. Można zatem wnioskować, że zarejestrowane ubytki masy są związane z uwalnianiem wody zaadsorbowanej na powierzchniach i w przestrzeniach międzypakietowych iłów.

Zależność pomiędzy ilością wody zaadsorbowanej a sumą iłów (rysunek 4a) dla wszystkich badanych próbek jest słaba. Wyraźnie wydzielają się tutaj dwie grupy skał: próbki mioceńskie i próbki dolnopaleozoiczne (rysunek 4b), w obrębie których uzyskano dobre korelacje $\left(R^{2}=0,87 ; 0,90\right)$. Obserwowane zjawisko wskazuje na to, że wielkość ubytku masy związanego $\mathrm{z}$ wodą zaadsorbowaną zależy nie tylko od ilości iłów, ale też od ich rodzaju. Najwyższe ubytki masy zarejestrowano w drobnoziarnistych skałach mioceńskich zawierających powyżej 45\% iłów. Mułowce dolnopaleozoiczne o zbliżonej zawartości iłów charakteryzują się znacznie niższym ubytkiem masy (tablica 1, rysunek 4b), co świadczy o tym, że istotną część ubytku masy stanowi woda międzypakietowa występująca w mniej zmienionych iłach mioceńskich. Wskazuje na to również dobra korelacja $\left(R^{2}=0,83\right)$ pomiędzy ilością wody zaadsorbowanej a parametrem pojemności wymiany kationowej CEC określającym zdolności do pęcznienia iłów (rysunek 5), uzyskana dla wszystkich próbek. Najlepszą korelację $\left(R^{2}=0,87\right)$ otrzymano, biorąc pod uwagę równocześnie sumę iłów i parametr CEC (rysunek 6). 


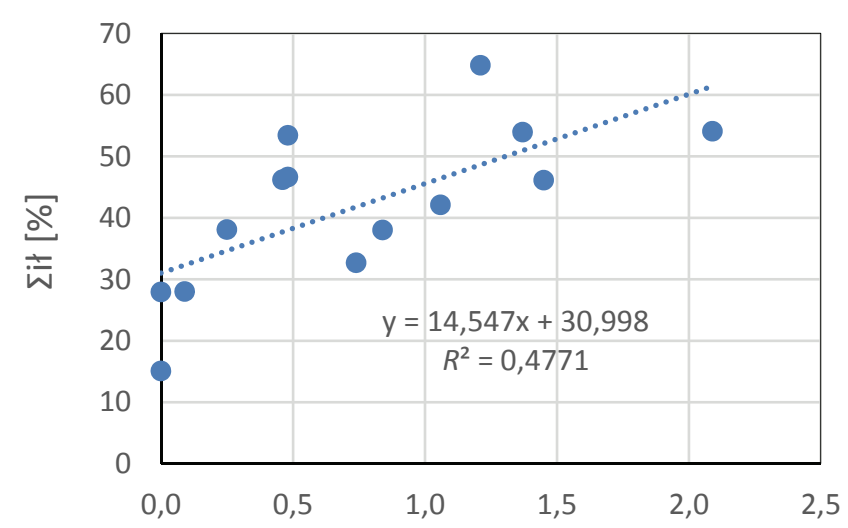

a)

$$
m_{\text {ads }}[\%]
$$

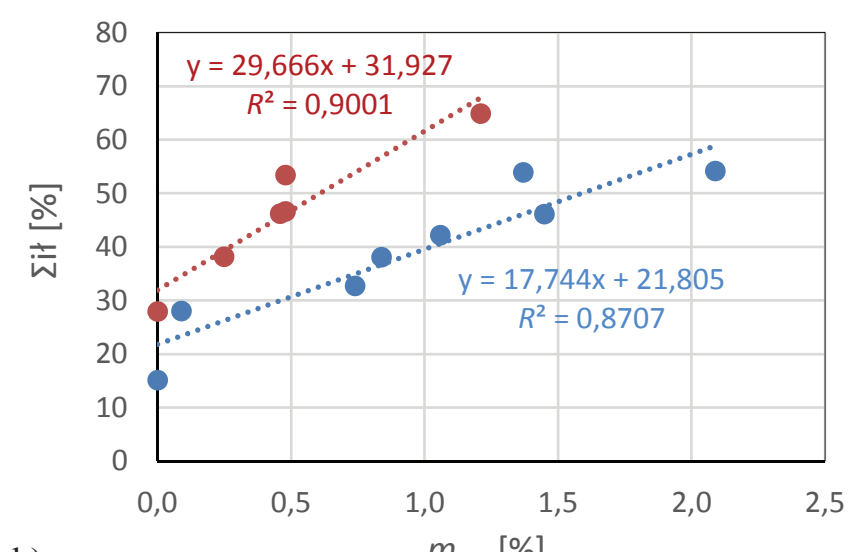

b)

$$
m_{\text {ads }}[\%]
$$

Rys. 4. Zależność pomiędzy ubytkiem masy związanym z wodą zaadsorbowaną na powierzchniach i w przestrzeniach międzypakietowych iłów ( $\left.m_{\text {ads }}\right)$ a sumą iłów ( $\Sigma$ ił): a) dla wszystkich próbek; b) z wydzieleniem grup skał mioceńskich i fliszowych (niebieskie punkty) oraz dolnopaleozoicznych (czerwone punkty)

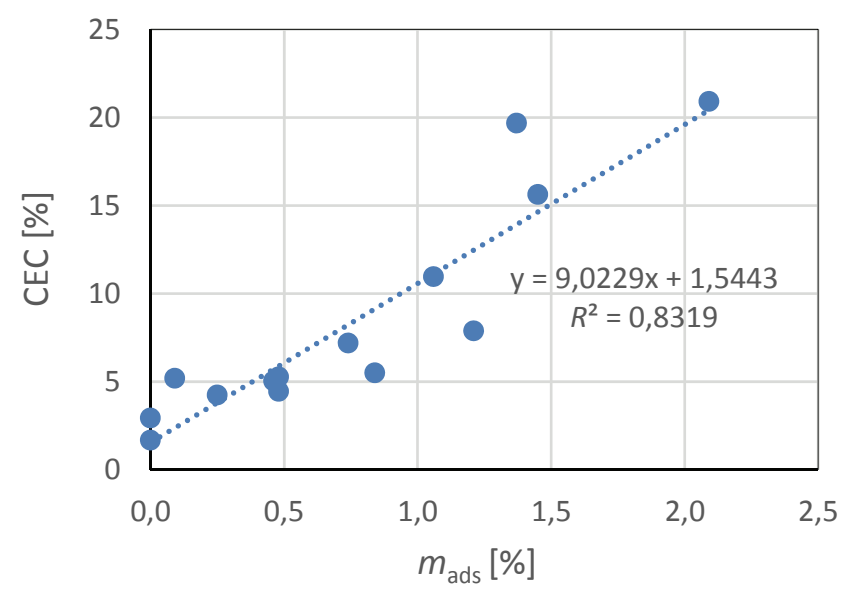

Rys. 5. Zależność pomiędzy ubytkiem masy związanym $\mathrm{z}$ wodą zaadsorbowaną na powierzchniach i w przestrzeniach międzypakietowych iłów $\left(m_{\text {ads }}\right)$ a pojemnością wymiany kationowej CEC

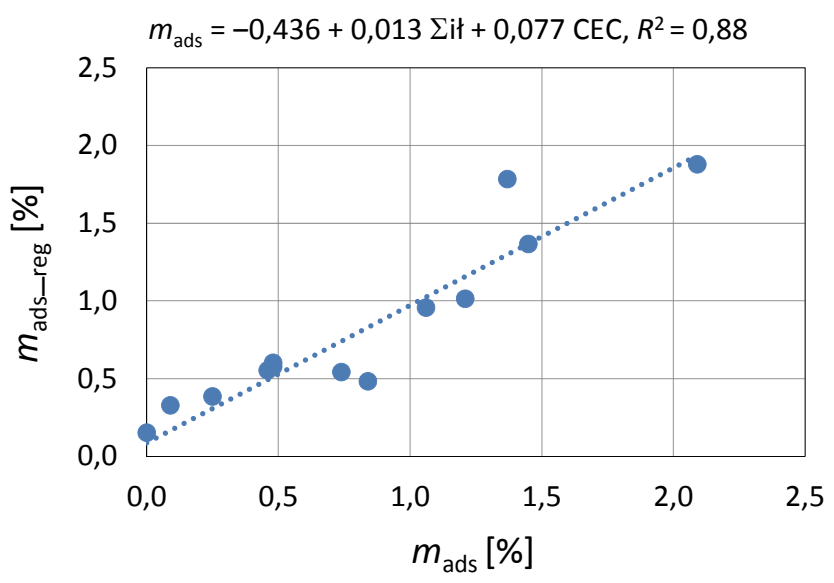

Rys. 6. Korelacja wartości ubytku masy związanego z dehydratacją iłów uzyskanych na podstawie pomiarów laboratoryjnych $\left(m_{\text {ads }}\right)$ i regresji wielokrotnej ( $\left.m_{\text {ads_reg }}\right)$. Zależność otrzymana dla dwóch parametrów: sumy iłów ( $\sum$ ił) i pojemności wymiany kationowej (CEC)

\section{Woda strukturalna}

Proces dehydroksylacji iłów (uwalnianie grup $\mathrm{OH}^{-}$związanych w strukturze iłów) rejestrowany jest na krzywych termicznych $\mathrm{w}$ temperaturach od około $480^{\circ} \mathrm{C}$ do $700^{\circ} \mathrm{C}$ $[2,3,7]$. Zakres temperatur zależy od rodzaju i ilości minerałów ilastych, przy czym temperatury reakcji dla poszczególnych minerałów nakładają się na siebie. Ubytek masy związany z dehydroksylacją iłów zaobserwowano dla większości badanych próbek w zakresie temperatur od około $440^{\circ} \mathrm{C}$ do $620^{\circ} \mathrm{C}$ (tablica 1 ). Stracie masy odpowiada efekt endotermiczny na krzywej DTA oraz refleks na widmie masowym wody (QMS). W przypadku trzech próbek $(2,7,13)$ temperatura końca reakcji jest nieco niższa, około $550^{\circ} \mathrm{C}$, co wynika z niewielkiej zawartości iłów. Dynamiczny charakter procesów zachodzących w próbce w trakcie podgrzewania powoduje, że zakresy temperatur, w których przebiegają poszczególne reakcje mogą ulegać zmianie, zależą bowiem od czynników takich jak ilość danej substancji czy rozdrobnienie próbki. Ubytek masy związany z dehydroksylacją iłów w badanych próbkach koreluje z sumą iłów $\left(R^{2}=0,65\right.$, rysunek $\left.7 \mathrm{a}\right)$. Dla wydzielonych osobno próbek mioceńskich uzyskano dobrą korelację $\left(R^{2}=0,80\right.$, rysunek 7b); w przypadku skał dolnopaleozoicznych zależność ta jest znacznie słabsza $\left(R^{2}=0,50\right.$, rysunek $\left.7 b\right)$. Rozbieżność ta jest związana z obecnością substancji organicznej, trzeba bowiem wziąć pod uwagę fakt, że zakresy temperatur, w których uwalniana jest woda strukturalna $\mathrm{z}$ iłów oraz zachodzi rozkład substancji organicznej, częściowo się pokrywają (tablica 1). Wpływ substancji organicznej na ubytek masy jest znacznie większy w próbkach dolnopaleozoicznych o wysokim TOC.

Uwzględnienie wpływu substancji organicznej na ubytek masy związany z dehydroksylacją iłów zdecydowanie poprawia uzyskane zależności $\left(R^{2}=0,79 ; 0,76\right.$; rysunki 8a, b). 

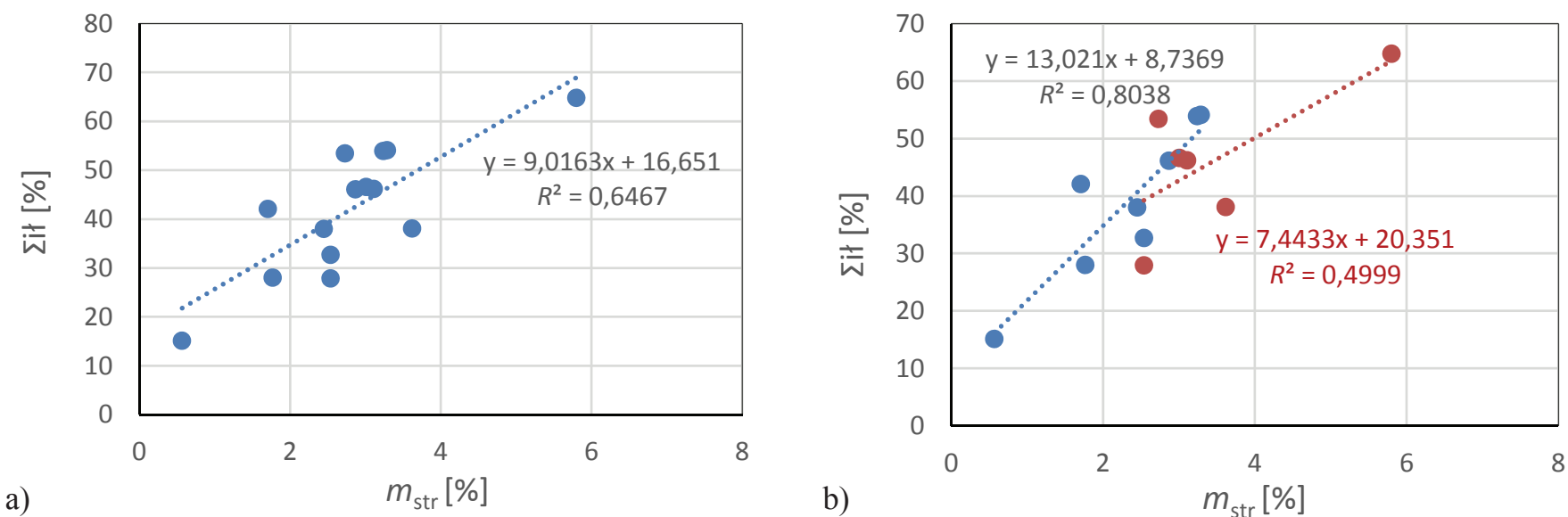

Rys. 7. Zależność pomiędzy ubytkiem masy związanym z wodą strukturalną ( $\left.m_{\text {str }}\right)$ a sumą iłów ( $\left.\Sigma i ł\right)$ : a) dla wszystkich próbek;

b) z wydzieleniem grup skał mioceńskich i fliszowych (niebieskie punkty) oraz dolnopaleozoicznych (czerwone punkty)
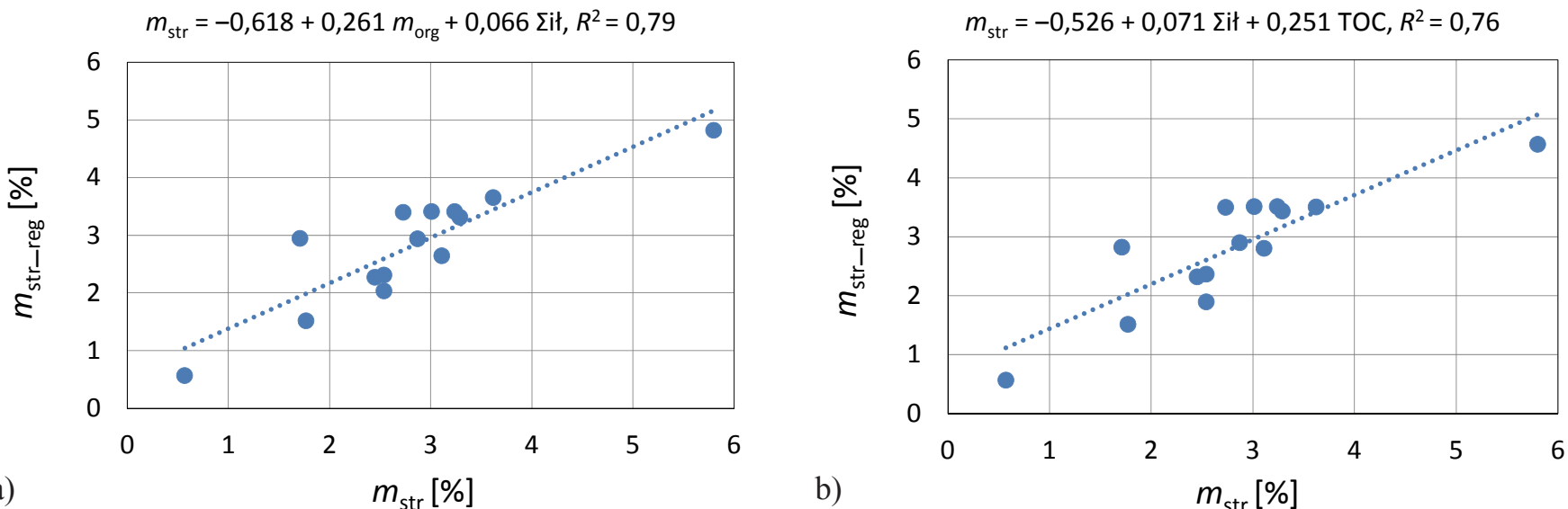

Rys. 8. Korelacja wartości ubytku masy związanego z dehydroksylacją iłów uzyskanych na podstawie pomiarów laboratoryjnych $\left(m_{\text {str }}\right)$ i regresji wielokrotnej $\left(m_{\text {str_eg }}\right)$. Zależność otrzymana dla dwóch parametrów: sumy iłów ( $\left.\Sigma i ł\right)$ i ubytku masy związanego z substancją organiczną $\left(m_{\text {org }}\right)($ a) oraz sumy iłów $(\Sigma i ł)$ i zawartości węgla organicznego TOC (b)

\section{Woda zwiazana z iłami}

Całkowity ubytek masy związany z iłami (suma wody zaadsorbowanej i strukturalnej) wynosi w badanych próbkach od $0,57 \%$ w próbce o najniższej (15\%) zawartości iłów do $7,01 \%$ w próbce najbardziej zailonej $(64,8 \%)$; dla większości próbek zawiera się w przedziale od 3,2\% do 4,6\% i dobrze koreluje z sumą iłów $\left(R^{2}=0,79\right.$, rysunek 9$)$.

Po uwzględnieniu w analizowanej zależności parametrów wpływających na poszczególne składowe $m_{\mathrm{i}}$, czyli współczynnika CEC (wpływa na $m_{\text {ads }}$ ), oraz ubytku masy związanego z organiką (wpływa na $m_{\text {str }}$ ) uzyskujemy lepszą korelację $\left(R^{2}=0,85\right.$, rysunek 10$)$.

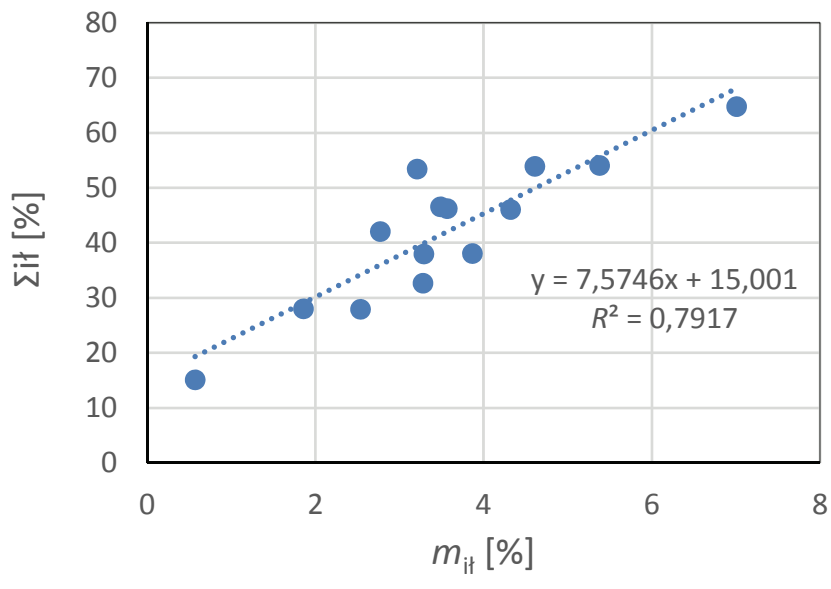

Rys. 9. Zależność pomiędzy całkowitym ubytkiem masy związanym z iłami $\left(m_{\mathrm{ił}}\right)$ a sumą iłów $(\Sigma i ł)$ 




Rys. 10. Korelacja wartości całkowitego ubytku masy związanego z iłami uzyskanych na podstawie pomiarów laboratoryjnych $\left(m_{\mathrm{ił}}\right)$ i regresji wielokrotnej $\left(m_{\text {ił_reg }}\right)$. Zależność otrzymana dla trzech parametrów: sumy iłów ( $\left(\sum i ł\right)$, pojemności wymiany kationowej (CEC) oraz ubytku masy związanego z substancją organiczną $\left(m_{\text {org }}\right)$

\section{Ubytek masy związany z substancją organiczną}

Efekty związane z rozkładem substancji organicznej rejestrowane są na krzywych termicznych w temperaturach od około $300^{\circ} \mathrm{C}[2,3,5]$. W badanych próbkach zaobserwowano pewną zmienność zakresu temperatur związaną ze spalaniem substancji organicznej. Proces ten zaczyna się w większości przypadków w temperaturze około $300^{\circ} \mathrm{C}$ (tablica 1). Na krzywej DTA widoczny jest pierwszy pik egzotermiczny powiązany $z$ wydzielaniem wody (rysunki 2,3 ). Jest to najprawdopodobniej woda pochodząca z rozkładu kwasów organicznych ([1] oraz informacja uzyskana od prof. I. Matyasik z INiG - PIB]. Kolejnym efektom egzotermicznym odpowiada wydzielanie $\mathrm{CO}_{2}$ (rysunki 2, 3). Dla czterech próbek, wyróżniających się wysoką zawartością minerałów ilastych, temperatura początku reakcji jest wyższa $\left(\operatorname{od} 350^{\circ} \mathrm{C}\right.$ do $475^{\circ} \mathrm{C}$ ), nie występuje tutaj pik egzotermiczny około $300^{\circ} \mathrm{C}$, powiązany z wydzielaniem $\mathrm{H}_{2} \mathrm{O}$. Temperatura końca reakcji dla próbek o wartości TOC $\leq 1$ wynosi około $500^{\circ} \mathrm{C}$, a dla próbek bogatszych w substancję organiczną rośnie wraz z jej zawartością (dla TOC $=5,35$ wynosi $550^{\circ} \mathrm{C}$ ). Zróżnicowanie to związane jest, tak jak w przypadku iłów, z dynamiką procesów zachodzących w próbce podczas podgrzewania - zakres temperatur charakterystycznych dla danej reakcji przesuwa się w stronę wartości wyższych wraz ze wzrostem ilości mierzonej substancji. Bardzo dobra korelacja ubytku masy z zawartością węgla organicznego TOC $\left(R^{2}=0,91\right)$ (rysunek 11) potwierdza prawidłowość oszacowania zakresu temperatur procesu spalania substancji organicznej i zasadność powiązania efektu występującego w temperaturze $300^{\circ} \mathrm{C}$ (pik egzotermiczny i refleks na widmie masowym wody) z rozkładem substancji organicznej.

Uwzględnienie wpływu straty masy związanej z dehydroksylacją iłów poprawia korelację $\left(R^{2}=0,94\right.$; rysunek 12$)$. Wynika to z tego, że zakresy temperatur, w których zachodzi dehydroksylacja iłów i rozkład substancji organicznej, częściowo się pokrywają (tablica 1).

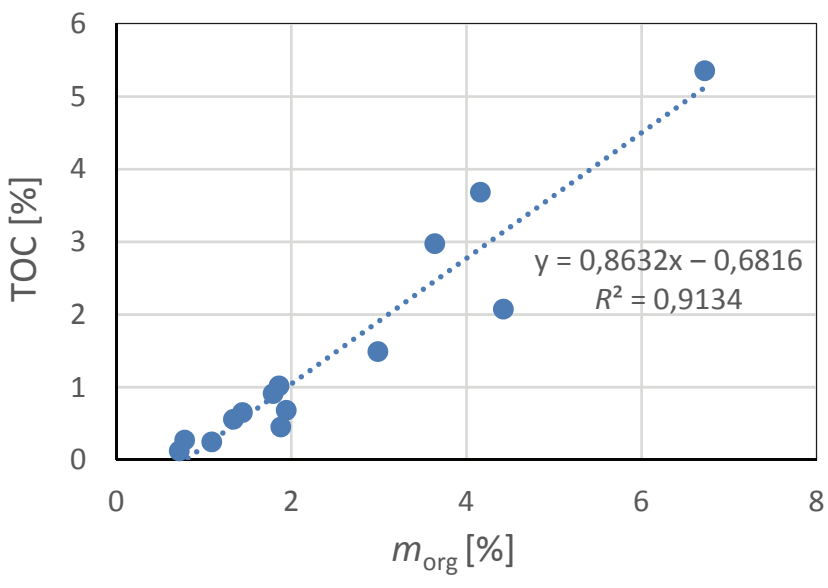

Rys. 11. Zależność pomiędzy ubytkiem masy związanym z rozkładem substancji organicznej a wartością TOC

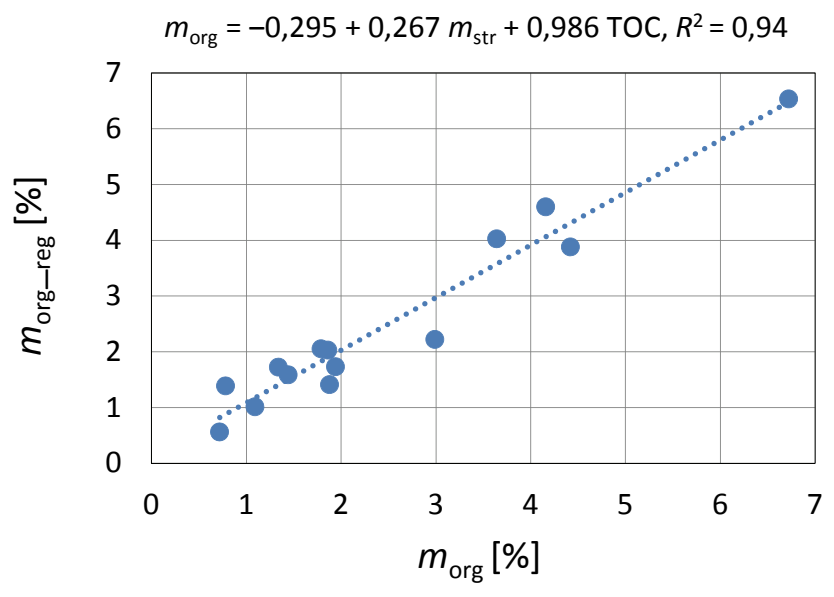

Rys. 12. Korelacja wartości całkowitego ubytku masy związanego z rozkładem substancji organicznej na podstawie pomiarów laboratoryjnych $\left(m_{\text {org }}\right)$ i regresji wielokrotnej $\left(m_{\text {org reg }}\right)$. Zależność uzyskana dla dwóch parametrów: zawartości węgla organicznego TOC oraz ubytku masy związanego $\mathrm{z}$ dehydroksylacją iłów $\left(m_{\text {str }}\right)$ 


\section{Inne efekty widoczne na krzywych termicznych}

Na krzywych termicznych wyraźnie zaznaczają się efekty związane z rozkładem węglanów. Ubytek masy występuje $\mathrm{w}$ większości próbek w zakresie temperatur od około $670^{\circ} \mathrm{C}$ do $790^{\circ} \mathrm{C}$, towarzyszy mu efekt endotermiczny na krzywej DTA oraz refleks na widmie masowym $\mathrm{CO}_{2}$ (rysunek 2). Ubytek masy związany z rozkładem węglanów dobrze koreluje z sumą węglanów określoną metodą XRD (rysunek 13).

Rozkład pirytu zaznacza się jako ubytek masy w zakresie temperatur $400 \div 500^{\circ} \mathrm{C}$ [2] i nakłada się na efekty związane $\mathrm{z}$ utlenianiem substancji organicznej. Ponieważ obu procesom towarzyszą refleksy egzotermiczne nie zawsze możliwe jest zidentyfikowanie efektu związanego z rozkładem pirytu. W dwóch badanych próbkach zawierających powyżej 5\% pirytu (zawartość określona metodą XRD) zaobserwowano bardzo wyraźne efekty egzotermiczne związane prawdopodobnie z utlenianiem tego minerału (rysunek 3). Na termogramach piaskowców mioceńskich i fliszowych zaznacza się pik endotermiczny w temperaturze $573^{\circ} \mathrm{C}$ odpowiadający przemianie fazowej kwarcu $\alpha \mathrm{w} \operatorname{kwarc} \beta$ [2]. Na większości krzywych widoczny jest nieostry (rozmyty) efekt egzo-

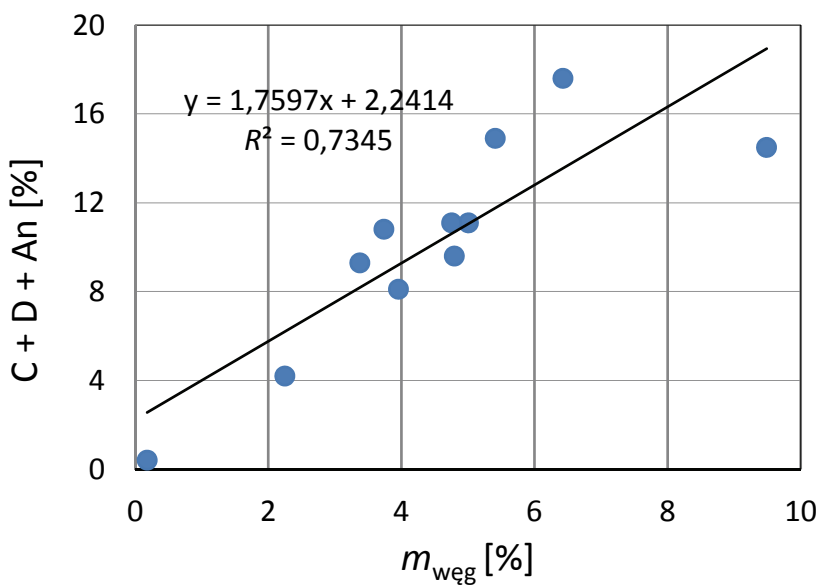

Rys. 13. Zależność pomiędzy sumą węglanów $(C+D+A n)$ określoną metodą XRD a ubytkiem masy związanym z rozkładem węglanów ( $\left.m_{\text {wẹg }}\right)$; $\mathrm{C}-$ kalcyt, $\mathrm{D}-$ dolomit, An - ankeryt

termiczny, bez ubytku masy (rysunek 2) w zakresie temperatur około $890 \div 910^{\circ} \mathrm{C}$, najprawdopodobniej związany z rekrystalizacją chlorytu i powstaniem nowych faz krystalicznych (oliwiny, spinele) [2,7].

\section{Podsumowanie i wnioski}

Analiza pomiarów termicznych pozwoliła na określenie zakresów temperatur charakterystycznych dla takich procesów jak: dehydratacja i dehydroksylacja minerałów ilastych, spalanie substancji organicznej i rozkład węglanów dla badanych skał. Przy interpretacji krzywych termicznych trzeba wziąć pod uwagę czynniki takie jak: skład i stopień rozdrobnienia skały, tempo pomiaru oraz ilość badanej substancji w próbce. Należy również pamiętać o tym, że wiele procesów zachodzących w próbce pod wpływem temperatury nakłada się na siebie (np. spalanie substancji organicznej i utlenianie pirytu). Analiza wyników uzyskanych dla układów wieloskładnikowych, jakimi są skały, nie jest więc prosta i jednoznaczna. Celem weryfikacji otrzymanych wyników skorelowano wyliczone na podstawie badań STA_QMS ubytki masy z innymi parametrami, takimi jak zawartość minerałów ilastych, pojemność wymiany kationowej (CEC) i ilość węgla organicznego (TOC).

W badanych próbkach ubytek masy związany z uwalnianiem wody $\mathrm{z}$ iłów obserwowany jest $\mathrm{w}$ dwóch zakresach temperatur: od $40^{\circ} \mathrm{C}$ do $150^{\circ} \mathrm{C}$ (woda zaadsorbowana) i od $440^{\circ} \mathrm{C}$ do $620^{\circ} \mathrm{C}$ (woda strukturalna). Całkowity ubytek masy związany z iłami (suma wody zaadsorbowanej i strukturalnej) dla większości próbek zawiera się w przedziale od 3,2\% do $4,6 \%$ i dobrze koreluje z sumą iłów $\left(R^{2}=0,79\right)$.
Ubytek masy wynikający z niższego zakresu temperatur $\left(40 \div 150^{\circ} \mathrm{C}\right)$ zinterpretowano jako pochodzący w całości od wody związanej z minerałami ilastymi; nie stwierdzono tutaj wody wolnej. W porowatych piaskowcach o niskim zaileniu nie zaobserwowano ubytku masy w początkowym zakresie temperatur. Można więc uznać, że woda wolna ulega uwolnieniu w trakcie przygotowania próbki do badań (rozdrobnienie do frakcji $<0,1 \mathrm{~mm}$ ). Zawartość wody zaadsorbowanej $\left(m_{\text {ads }}\right)$ zależy zarówno od ilości, jak i rodzaju materiału ilastego. Skały mioceńskie zawierające iły pęczniejące charakteryzują się znacznie wyższą ilością wody zaadsorbowanej niż mocno zdiagenezowane mułowce dolnopaleozoiczne o zbliżonej zawartości iłów. Najlepszą korelację pomiędzy $m_{\text {ads }}$ a sumą iłów $\left(R^{2}=0,83\right)$ uzyskano, uwzględniając wpływ parametru CEC (charakteryzującego zdolności iłów do pęcznienia).

Zakres temperatur, w którym uwalniana jest woda strukturalna $\left(440^{\circ} \mathrm{C}\right.$ do $\left.620^{\circ} \mathrm{C}\right)$, pokrywa się częściowo z temperaturami rozkładu substancji organicznej, co należy wziąć pod uwage przy analizie ubytku masy związanego z dehydroksylacją iłów $\left(m_{\text {str }}\right)$. Zależność pomiędzy $m_{\text {str }}$ a sumą iłów (dla wszystkich badanych próbek) charakteryzuje się współczynnikiem korelacji $R^{2}=0,64$. Uwzględnienie wpływu ubytku masy związanego z substancją organiczną $\left(m_{\text {org }}\right)$ 
znacząco poprawia uzyskaną korelację $\left(R^{2}=0,79\right)$. Dla wydzielonych osobno próbek mioceńskich i fliszowych otrzymano dobrą korelację $m_{\text {str }}$ z sumą iłów $\left(R^{2}=0,80\right)$; w przypadku skał dolnopaleozoicznych o znacznie wyższej zawartości substancji organicznej zależność ta jest zdecydowanie słabsza $\left(R^{2}=0,50\right)$, co świadczy o tym, że wpływ zawartości węgla organicznego dotyczy przede wszystkim próbek o wysokim TOC.

Analizy termiczne mogą również znaleźć zastosowanie do badań substancji organicznej. Ubytek masy związany z rozkładem substancji organicznej rejestrowany w badanych próbkach w zakresie temperatur od $300^{\circ} \mathrm{C}$ do $550^{\circ} \mathrm{C}$ bardzo dobrze koreluje $\left(R^{2}=0,91\right)$ z zawartością węgla organicznego TOC. Uwzględnienie w korelacji ubytku masy wynikającego $\mathrm{z}$ dehydroksylacji iłów $m_{\text {str }}$ poprawia uzyskaną zależność $\left(R^{2}=0,94\right)$.

Symultaniczna analiza termiczna STA sprzężona z pomiarami kwadrupolowym spektrometrem masowym QMS stanowi cenne uzupełnienie zarówno badań mineralogicznych, jak i petrofizycznych. Jest szczególnie przydatna w charakterystyce skał ilastych, daje możliwość oszacowania ilości wody związanej z iłami, a także rozróżnienia pomiędzy wodą zaadsorbowaną na powierzchniach i w przestrzeniach międzypakietowych iłów oraz związaną siłami kapilarnymi a wodą związaną w strukturach minerałów ilastych.

Prosimy cytować jako: Nafta-Gaz 2017, nr 7, s. 479-487, DOI: 10.18668/NG.2017.07.05

Artykuł nadesłano do Redakcji 9.12.2016 r. Zatwierdzono do druku 14.04.2017 r.

Artykuł powstał na podstawie pracy statutowej pt.: Badanie skał o różnym stopniu zailenia i zawartości substancji organicznej metodami termicznymi i NMR - praca INiG - PIB na zlecenie MNiSW; nr zlecenia: 05/SW/16, nr archiwalny: DK-4100-5/16.

\section{Literatura}

[1] Durand B.: Kerogen: Insoluble Organic Matter from Sedimentary Rocks. Editions Technip Paris 1980.

[2] Földvari M.: Handbook of thermogravimetric system of minerals and its use in geological practice. Occasional Papers of the Geological Institute of Hungary 2011, vol. 213.

[3] Gips J.P: Shale Characterization Using TGA, Py-GC-MS, and NMR. Msc Thesis, The University of Texas, Austin 2014.

[4] Handverger D.A., Suarez-Rivera R., Vaughn K.I., Keller J.F.: Improved petrophysical core measurements on tight shale reservoirs using retort and crushed samples. SPE Paper 147456, SPE Annual Technical Conference and Exhibition, Denver, USA 30.10-02.11.2011.

[5] Kaljuvee T., Keelmann M., Trikkel A., Kuusik R.: Thermooxidative decomposition of oil shales. J. Therm. Anal. Calorim. 2011, vol. 105, s. 395-403.

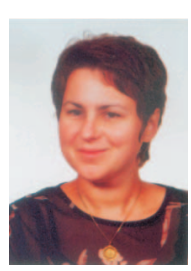

Mgr Anna PRZELASKOWSKA

Starszy specjalista badawczo-techniczny

w Zakładzie Geofizyki Wiertniczej.

Instytut Nafty i Gazu - Państwowy Instytut Badawczy

ul. Lubicz 25 A

31-503 Kraków

E-mail: anna.przelaskowska@inig.pl

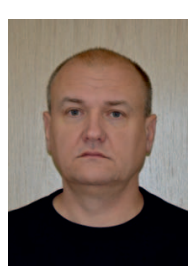

Dr hab. inż. Piotr P. KULINOWSKI

Prof. Uniwersytetu Pedagogicznego

Instytut Techniki

Uniwersytet Pedagogiczny im. Komisji Edukacji

Narodowej

ul. Podchorążych 2, 30-084 Kraków

E-mail:pkulino@up.krakow.pl
[6] Kowalska S.: Określenie ilościowego sktadu mineralnego skat zawierajacych minerały ilaste metoda Rietvelda. Nafta-Gaz 2013, nr 12, s. 894-902.

[7] Labus M., Labus K., Bujok P.: Determination of the pore space parameters in microporous rocks by means of thermal methods. Journal of Petroleum Science and Engineering 2015, vol. 127 , s. 482-489.

[8] Przelaskowska A., Łykowska G., Klaja J., Kowalska S., Gąsior I.: Wykorzystanie parametru pojemności wymiany kationowej CEC do charakterystyki zdolności pęcznienia skat ilastych dolnego paleozoiku, fliszu karpackiego i miocenu zapadliska przedkarpackiego. Nafta-Gaz 2015, nr 6, s. 384-389.

[9] Stoch L.: Mineraty ilaste. Wydawnictwo Geologiczne. Warszawa 1974.

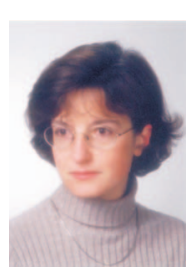

Mgr inż. Jolanta KLAJA

Starszy specjalista inżynieryjno-techniczny

w Zakładzie Geofizyki Wiertniczej.

Instytut Nafty i Gazu - Państwowy Instytut Badawczy ul. Lubicz 25 A

31-503 Kraków

E-mail: jolanta.klaja@inig.pl

Mgr Adam GAWEL

Wydziałowe Laboratorium Badań Fazowych, Strukturalnych,

Teksturalnych i Geochemicznych.

Wydział Geologii, Geofizyki i Ochrony Środowiska; AGH

al. Mickiewicza 30 30-059 Kraków

E-mail:agawel@agh.edu.pl 